\title{
TWO KINDS OF 'CHRISTIAN PHILOSOPHY'
}

\author{
WINFRIED LÖFFLER
}

University of Innsbruck

\begin{abstract}
It is controversial whether 'Christian Philosophy' is a useful or even consistent notion. After providing some historical background to the problem, I will distinguish and explicate two possible understandings of 'Christian Philosophy' which should be kept apart: a 'Thomistic' and an 'Augustinian' one, of which the latter has garnered more attention in the recent literature. A sketch of the most prominent current 'Augustinian' position (Alvin Plantinga's 'Reformed Epistemology') leads to some considerations for why a 'Thomistic' understanding of 'Christian Philosophy' has more to recommend it, if the term is regarded as useful at all.
\end{abstract}

An obvious touchstone for understanding how a religion relates to the idea of reasoning and giving reasons is its relation to philosophy. Now for various reasons not all religions have an (in any way elaborate) relation to philosophy, but some in fact do: there is frequent talk of 'Christian Philosophy', 'Islamic Philosophy' and/or' 'Muslim Philosophy', 'Jewish Philosophy', 'Buddhist Philosophy', and so forth. On the other hand, such terms face constant worry and are often rejected: the very idea of a philosophy with some religious epithet or branding seems to many people philosophically unacceptable, or undesirable for religious reasons, or even both. In the present article I explore the prospects for someone who wants to preserve the term 'Christian Philosophy' (and

${ }^{1}$ I mention both terms here since the question of a difference in meaning between them is non-trivial. Roughly, 'Muslim philosophy' is mostly understood as philosophy that is/was done by Muslims, whereas 'Islamic philosophy' is philosophy with a religious orientation inspired by Islam. This distinction does not correspond to my later distinction; but within Islamic philosophy there are discussions going on which are comparable to the debates between 'Thomistic' and 'Augustinian' Christian philosophy to be discussed here. 
there are, I think, certain reasons for preserving it). Presumably, the results of my considerations might, mutatis mutandis, also be relevant for Islamic, Jewish and other philosophies. After an exposition of the problem in section I, I will briefly call to mind a historical debate from the 1920s and 30s on the notion of 'Christian Philosophy' (section II). My subsequent analysis requires a certain methodological abstraction concerning religions (section III), on the background of which I will in section IV expose the crucial distinction between 'Augustinian' and 'Thomistic' Christian Philosophy, which revolves around different structures of philosophical reasoning. To illustrate the relevance of the distinction, I will in section $\mathrm{V}$ briefly recap what is probably the most prominent current 'Augustinian' position: Alvin Plantinga's 'Reformed Epistemology', a critical assessment of which leads to some general remarks about why the 'Thomistic' approach has, all in all, more to recommend it, if the notion of 'Christian Philosophy' is taken to be fruitful at all (section VI).

\section{THE PROBLEM}

The worry that 'Christian Philosophy' might be an internally incoherent notion has to do with widespread semantic intuitions about 'philosophy'. Although there is to my knowledge no universally accepted definition of philosophy, I think that many people would explicate it something like this (at least this is the most adequate explication I have found so far):

Philosophy is the systematic attempt to understand how everything hangs together based on one's own insight. Studying philosophy makes methodical use of the results of others' attempts. ${ }^{2}$

Some swift comments on this explication might be in order. Philosophy is a systematic attempt (unlike, e.g., art, which also sometimes tries to understand how everything hangs together); it is an attempt (i.e., it is more like an ongoing activity and less like a completed, available stock of knowledge); and its primary target is how everything hangs together, whereas the special sciences investigate to special kinds, aspects, sectors, or parts of reality. Unlike religions, political or other ideologies, it hopes to achieve this goal by relying on the philosopher's own insight, i.e., not on faith or commitment to some tradition, revelation or the like. The last

2 Otto Muck, Christliche Philosophie (Kevelaer: Butzon \& Bercker, 1964), 20, my translation. 
clause in the explication makes clear that philosophy does not consist merely in repeating philosophical statements made by others, but that adoptions of others' philosophical views must have some methodical backing. It must be stressed that philosophy is not identical with the history of philosophy, even if the knowledge of its own history is more important for philosophy than for other scholarly disciplines.

The problem concerning 'Christian Philosophy' revolves, of course, around the clause 'based on one's own insight'. Religions like Christianity usually claim that they are not accepted on thinkers' own insight, at least not completely, but rather on insight emendated by something else, like reliance on some tradition or revelation, an enhancement of cognition by a supernatural addendum like insight by faith, etc. Hence, 'Christian Philosophy' seems to be a self-contradiction, and this explains some well known verdicts of it. Martin Heidegger, for example, in his 1927 essay Phänomenologie und Theologie, ${ }^{3}$ criticizes the idea as a 'wooden iron', and the prominent Swiss Reformed theologian Karl Barth holds that

... there never has actually been a philosophia christiana, for if it was philosophia it was not christiana, and if it was christiana it was not philosophia. ${ }^{4}$

But on the other hand there seem to be good arguments which contradict these statements, from historical as well as systematic standpoints:

(1) Historically, certain epochs in (Western) philosophy are simply not understandable without considering their factual religious background in Jewish, Christian, and Islamic faith. It is a fact that over long centuries, almost everyone whom today's history of philosophy textbooks list as a philosopher was also a theologian, and there was even no clear methodological distinction between philosophy and theology until the 13 th century. This distinction was only made by Scholastics like Albert the Great and especially Thomas Aquinas.

Likewise, important philosophical ideas such as 'history', 'person', 'free will', 'human rights', 'law of nature, etc., have either only distant predecessors in Greco-Roman philosophy or none at all, but they were evidently inspired by their Judaeo-Christian-Islamic theological roots. Hence, at least in certain past epochs, one could talk about a 'Christian Philosophy'.

3 'Phänomenologie und Theologie' (1927), in: Wegmarken (Gesamtausgabe I/9) (Frankfurt: Klostermann 1976), 66.

${ }^{4}$ Karl Barth, Church Dogmatics (1932, English tr. 1936), I/1, § 1, 6. 
(2) From a rather hermeneutico-epistemological standpoint, one might doubt whether something like the oft-desired 'presuppositionfree philosophy' is really within reach. Is it really possible to completely distance oneself as a philosopher from any influences of the background tradition(s) within which one was brought up? Notably, Hans-Georg Gadamer in his Truth and Method (1960) claimed that it is most probably not possible. As a way out, Gadamer partially rehabilitated traditions from the common suspicion that they inevitably blindfold us. He stated that it is rather the philosopher's task to get into the 'horizon of understanding' of other thinkers and thereby gain awareness of one's own horizon which might otherwise remain unnoticed. The experiences of philosophers who had occasion to become acquainted with distant philosophical cultures seem to support Gadamer's thesis (e.g., for European philosophers, contact with Far-Eastern philosophies is usually fruitful in discovering typical European mindsets which do not go without saying, and viceversa). If this is correct, it appears that most probably every philosopher (consciously or not) does some kind of ' $X Y$-ian philosophy' (the influences might be from religious, philosophical, political, or other traditions), without thereby disqualifying himself as a philosopher. One could hence conclude that a 'Christian Philosophy' would not per se be less legitimate than other $X Y$-ian philosophies, and even that sincerity and perspicuity require laying bare the worldviews within which we operate.

\section{THE DEBATE IN THE 1920/30s}

In order to find a way out of this problem, it is useful to briefly recall a very similar debate in the 1920s and 30s about the possibility and legitimacy of 'Christian Philosophy' which is widely forgotten today, ${ }^{5}$ but which

\footnotetext{
${ }^{5}$ An exception is Gregory Sadler, whose extensive publications over the last years have brought this debate back into focus. For an overview, see his freely accessible articles: 'The 1930s Christian Philosophy Debates', in Acta Philosophica, 21 (2012), 393-406, available at: <http://www.academia.edu/2180852/The_1930s_Christian_Philosophy_ Debates_Bibliografica_Tematica> (accessed 04/04/2013), and: 'Christian Philosophy: The 1930s French Debates' (2009), in: Internet Encyclopedia of Philosophy, available at: <http://www.iep.utm.edu/chri1930/> (accessed 04/04/2013). The most important texts of the French discussion were recently republished by him in English: Gregory B. Sadler (ed.), Reason Fulfilled by Revelation: The 1930s Christian Philosophy Debates in France (Washington: Catholic University of America Press, 2011). See also Ralph McInerny, 'Reflections on Christian Philosophy', in Linda Zagzebski (ed.), Rational Faith: Catholic Responses to Reformed Epistemology (Notre Dame: University of Notre
} 
attracted much attention in those days. In a couple of writings and lectures, the French historian of philosophy Étienne Gilson had claimed that the philosophy of late antiquity and the middle ages could duly be called 'Christian Philosophy', since many philosophical topics had emerged against the backdrop of Christian theology, and on neither a personal nor an institutional level could you distinguish between philosophy and theology in those epochs. Even if the epistemological distinction between philosophical and theological arguments was addressed here and there, revelation was commonly and unproblematically seen as a support of reason. (It might be added that a really clear methodological distinction between philosophy and theology was not available before the mid-13th century, when it appeared in the works of Thomas Aquinas.) Gilson provoked a harsh reaction by the French historian of philosophy Emile Bréhier, who claimed in a 1931 conference paper entitled 'Is there a Christian Philosophy?' ${ }^{6}$ that the idea of a 'Christian Philosophy' would be as absurd as 'Christian mathematics'. The debates (which consisted in numerous journal articles and a couple of meetings) ${ }^{7}$ climaxed at the 1933 conference of the French Thomist Society at the Dominican convent of Juvisy-sur-Orge near Paris. The texts from this conference were published in a volume entitled La philosophie chrétienne. ${ }^{8}$

The main result of the debates was an increasing awareness that two ${ }^{9}$ basic conceptions of 'Christian Philosophy' could be distinguished, and that the question 'Is there a Christian Philosophy?' should best be treated on the basis of this distinction. The two types are frequently labelled as an 'Augustinian' versus a 'Thomistic' understanding of Christian Philosophy.

Dame Press, 1992), 256-279, for the bigger historical context the three volumes Emerich Coreth - Georg Pfligersdorffer (eds.), Christliche Philosophie im katholischen Denken des 19. und 20. Jahrhunderts (Graz etc.: Styria, 1987-1990), and for the German-speaking realm Heinrich M. Schmidinger, 'Die christliche Philosophie des 20. Jahrhunderts im deutschen Sprachraum. Eine philosophiegeschichtliche Skizze', in Salzburger Jahrbuch für Philosophie, 35 (1990), 105-123.

${ }^{6}$ Emile Bréhier, 'Y-a-t'il une philosophie chrétienne?', in Revue de Métaphysique et de la Morale, 38 (1931), 133-162.

${ }^{7}$ For literature on the historical details, see footnote 2 above.

${ }^{8}$ Société Thomiste (ed.), La philosophie chrétienne, Juvisy 11 Septembre 1933 (Journées d'études de la Société Thomiste 2) (Paris: Cerf, 1933). See also the English texts in Sadler 2011 (see footnote 5 above).

${ }^{9}$ At the outset, there were more conceptions proposed than just these two. But the historical details are not the principal concern of this paper; see Sadler 2009 and 2012 (footnote 5 above). 
These labels are somewhat anachronistic in that neither Augustine (354430) nor Thomas Aquinas (1224/25-1274) explicitly elaborated on the notion of a 'Christian Philosophy' (discussions on that issue came up centuries later!). But Augustine's and Thomas's overall approaches to philosophy, especially their ways of relating the deliverances of faith and reason, can be seen as examples for these two conceptions. As a methodological prerequisite for their explication (in section IV), I will in section III introduce an abstraction concerning religions.

\section{A METHODOLOGICAL ABSTRACTION: RELIGIONS AS SETS OF PROPOSITIONS}

Religions are notably complex phenomena displaying many features: they have a social aspect, i.e., they are practiced in more or less structured groups with 'experts' and 'functionaries' (like priests, prophets, shamans, monks, etc.); they have rituals of various kinds; holy places, times, or objects; they usually have some moral behaviour code influencing private and public behaviour (think of the 10 Commandments in Judaism and Christianity, the Catholic social doctrine, Jewish and Islamic food guidelines, and various forms of taboo); some religions claim a history which is crucial for their self-understanding; they usually offer something like a world-picture answering ultimate questions (about where we come from and will be going to, what life is ultimately good for, etc.), and they have something like a theory-like, cognitive core of propositions. E.g., Christians on the one hand and Jews and Muslims on the other disagree about propositions like 'God is one and unique, but in him there is also some multiplicity' versus 'God is radically one.' The list of features may not be complete, and of course, various religions display these features in varying intensities. For example, there are religions which place great weight on the ritual side and do not emphasize their cognitive core, but the opposite weighting is also possible; the visibility and structure of the group may differ significantly; and likewise the importance of religious morals, taboo-like behaviour, etc., may vary between religions. Nevertheless, a minimum cognitive core seems to be present in any religion.

For my present task, I will concentrate on this cognitive core: religions are considered as if they were sets of propositions (or sets of beliefs in

${ }^{10}$ I owe this idea especially to Joseph M. Bochenski's still underrated but in my view classical book The Logic of Religion (New York: New York University Press, 1965). 
these propositions). ${ }^{10}$ Sets of propositions are the material of which an analytically oriented epistemological approach to religion has best grip. I am of course fully aware that this cognitivist approach has had an at least ambivalent history in the philosophy of religion; the ritual side of religions has especially been neglected by philosophy. Let me thus stress that this methodological move is just an abstraction and not a reduction. The existence and relevance of the other facets of religion are hereby not denied, and I definitely do not want to advocate the reductionist error that religions are nothing but sets of propositions.

A second constraint is my focus on religions which claim to have an access to sources of religious information beyond the deliverances of common human reason. The most prominent examples are the socalled 'revelation religions', of which the best-known are Christianity, Islam, and Judaism. However, there are many more examples, such as Mormonism or the Baha'i religion. This constraint is being made because the distinction between 'Augustinian' and 'Thomistic' Christian Philosophy has to do with the way in which the deliverances of common human reason and these additional sources relate.

\section{IV. 'AUGUSTINIAN’ AND ‘THOMISTIC’ CHRISTIAN PHILOSOPHY}

Bearing these methodological preliminaries in mind, let us think of a religious believer's belief system as a vast set ${ }^{11}$ of propositions of which a certain subset can only be known by relying on revelation (i.e., the 'theological beliefs' in a narrower sense), whereas the bigger bulk of his knowledge can be acquired by natural reason alone, and hence in principle by anyone. ${ }^{12} \mathrm{~A}$ common example which is often mentioned

${ }^{11}$ A further simplification in my approach lies in the fact that the whole network of relations between the beliefs (psychological connections and logical support of various kinds) is not considered here and the beliefs are rather taken atomistically. But of course I do not thereby want to suggest that this atomistic picture is psychologically or epistemologically realistic. (I make this abstraction because considering these relations leads to a whole nest of related problems which cannot be addressed here: e.g., the problem of the role which non-revelation-based propositions play in the support of revelation-based beliefs (commonly treated under the label 'analysis fidei') or the nature of conclusions from a 'mixed' set of (non-)revelation-based premises (which was at times discussed under the label 'conclusio theologica').)

${ }^{12}$ Alvin Plantinga repeatedly and rightly remarked that, in philosophy and worldviewrelated issues, there are hardly any important beliefs which are held by virtually everyone, since matters here are notoriously controversial (see, e.g. his 'Augustinian Christian Philosophy', in The Monist, 75 (1992), 293f.). This is right; but the important demarcation 
in this context is the doctrine of the Holy Trinity: that God exists is (according to the classical view) a deliverance of natural reason alone, whereas the triune nature of God can only be known ${ }^{13}$ on the basis of revelation. In the following graphical model of the belief-system of an idealized believer, the doctrine of the Holy Trinity would be a member of the gray subset, and God's existence a member of the white one:

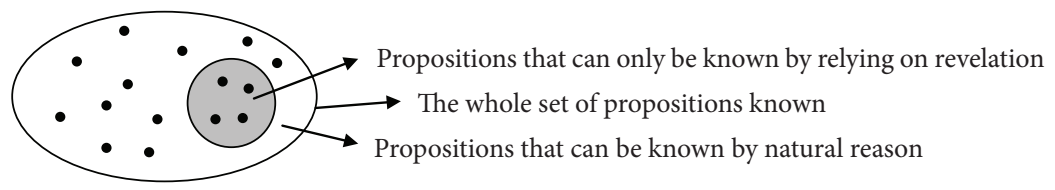

The central question, which leads to the distinction between the two forms of 'Christian Philosophy', is the following: Where in this belief system can philosophical reasoning start, i.e., from which subsets of propositions may its premises be taken, and what is 'Christian Philosophy' supposed to achieve?

IV.1. The 'Augustinian' Christian philosopher would provide the following answer: Concerning methodology, we may - as philosophers! also use what we can only know from revelation. The form of question which is typically posed in that style of Christian philosophy is this: 'What would follow for some topic XY if the Christian doctrines were true?' That is, the Christian doctrine is used as a source of (at least hypothetically acceptable) premises for philosophy.

The task of philosophy, so understood, consists in developing and defending a consistent, coherent and comprehensive Christian worldview. From this perspective, even projects like a 'Christian epistemology', a 'Christian set theory' or a 'Christian probabilistic confirmation theory' ${ }^{14}$ could - against Bréhier's verdict - indeed make sense, at least in principle. The Augustinian Christian thinker might even claim to provide some

to be drawn here is the one between propositions which are notoriously unaccepted by many people (since they are revealed only) and the rest of our beliefs.

${ }^{13}$ A disclaimer: I speak of 'knowledge' here and in the following passages in a nontechnical sense. I use the word mainly for the flat-footed reason that the alternative wording 'can only be believed on the basis of revelation' would sound odd. But I do not intend thereby to claim anything about whether or not beliefs about theological issues may constitute knowledge (in any explication of this word).

${ }^{14}$ See Richard Otte, 'A Theistic Conception of Probability', in Faith and Philosophy, 4 (1987), 424-447. 
explanatory surplus in these fields in comparison to secular scholars. For example, the notorious process/result-ambiguity concerning the word Zusammenfassung ('collection') in Cantor's famous definition of sets (i.e., is this collection something already present or is it made/created by the cognizing mind? And if the latter, how can human minds create enough of them to make set theory work?) might be settled in a certain direction: since the eternal, infinite God's omniscient mind knows all sets, they all - at least from our human perspective - exist already, and they are something we discover rather than create. This endorses a modest realist understanding of sets (from the human perspective) backed by a sort of theistic constructivism. ${ }^{15}$ Another example is the notorious problem of how to justify the convergence in probability judgments by different observers within Bayesian confirmation theory: is this convergence a theoretical consequence or an additional (and dubious) synthetic a priori assumption? Christian Bayesian conformation theorists of the Augustinian temperament might provide a solution: since we are 'created in God's image' according to Christian anthropology, God will also have enabled us to participate in his ability to cognize the truth. And hence, it is no wonder that the judgments of rational observers will in the long run converge.

So understood, Christian philosophy is primarily an internal service for the Christian community and its intellectual needs. Since premises from the realm of faith are used, it will be of limited relevance for external dialogue, but this is no problem: the task of philosophy is not so much to make Christian faith attractive to non-believers, but rather to provide an internally attractive vision of it. However, if there are opponents, they are of course invited to raise their objections and discuss them with Christian philosophers.

IV.2. The 'Thomistic' understanding of Christian philosophy follows a different methodology: the philosopher is advised to proceed as far as possible with 'worldview-neutral' premises (i.e., premises which are in principle accessible to anybody), and especially, philosophers must not use premises which are only known from revelation. Only where important questions remain open - and who would deny that this is often the case in philosophy? - may the Thomistic Christian philosopher

${ }^{15}$ So I take Plantinga's position in 'Advice to Christian Philosophers', in Faith and Philosophy, 1 (1984), $269 \mathrm{f}$. 
propose answers from Christian doctrine. But he does not do this in his competence and authority as a philosopher; he rather switches to a theological solution when philosophical solutions are not to hand. To cash out some rather simple examples, as a proposed answer to the question of the ultimate meaning of life, he might refer to the Christian doctrine of creation out of God's love, which bestows any creature its immanent value and dignity; or as a possible solution to the problem of evil, he might recall that Jesus Christ's non-violent undergoing of violence and death, as well as his resurrection, are hints that evil and death are not the final chapters of the world's story.

Nevertheless, the Thomistic Christian philosopher is a Christian, and as such, he sometimes has certain preferences in his philosophical interests: he tends toward philosophical opinions which seem compatible with his worldview. But as a philosopher, he would not argue for these opinions with premises from faith - he would pose questions of the following type: 'what good (but worldview-neutral!) arguments could lead to conclusions close to Christian doctrines?' For example, he would have a natural interest in the existence of free will, the universality of human rights, the existence of God, etc., and look for ways to defend them philosophically.

As Franz Brentano, Jacques Maritain and others put it metaphorically, the Christian doctrine is from this viewpoint just a guiding star for the philosopher: it tells the philosopher where his reasoning could possibly go - just like sailors on the open sea use the guiding star to decide on their course.

There is of course a background assumption behind Thomistic Christian Philosophy: The Thomistic Christian philosopher expects that there might be apparent, prima facie contradictions between religious doctrine (rightly understood) and scientific/philosophical knowledge (rightly understood), but that there cannot be an ultimate, unresolvable contradiction since God is the source of all truth and has equipped us with reason to grasp it. Admittedly, this background assumption is theological in nature, but this is unproblematic: it is an assumption that is made only by the Christian philosopher himself and does not oblige anybody else (it is, so to speak, an assumption made by Christians and for Christians). Apparent, prima facie contradictions between faith and reason may emerge where methodological and theoretical boundaries are overstepped. The debates about creation and evolution 
provide examples for such cases: wherever theologians try to emendate biological theories or biologists feel in a position to answer questions on the ultimate meaning of life, conflicts are to be expected. Hence on closer inspection this background assumption has a critical potential in various directions. It is not only directed against attempts to extrapolate worldview claims from the deliverances of the sciences. The Christian philosopher must also be prepared to discover that he or his community previously misunderstood, at least in part, their own religious tradition. Again, there are historical examples for such (sometimes slow and painful) discoveries: Galileo's case, for example, is an important stage on the way toward discovering that the Biblical tradition is not meant as a scientific account of the structure of the solar system and the universe. ${ }^{16}$

The tasks of philosophy according to the 'Thomistic' approach are to show that Christian faith is compatible with up-to-date (and properly understood) science and philosophy, and - more than the 'Augustinian' Christian philosopher would agree - to make it externally plausible. Adapting our graphical model of the structure of belief systems and philosophical arguments within them, one might bring out the difference as follows:

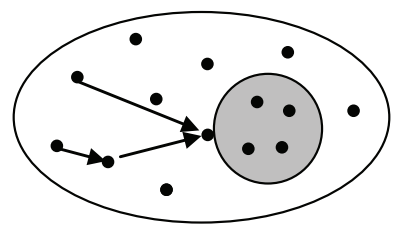

Thomistic pattern of argument

The arrows symbolizing logical support-relations in philosophical arguments depart from non-revealed propositions only. The dot touching the borderline of the revealed subset symbolizes a proposition which is in the vicinity of specifically Christian doctrines (an example could be the (philosophical) proposition that human beings have a particular dignity, which is in the vicinity of the (revealed) doctrine that human beings are God's creatures).

16 Of course, I do not want thereby to suggest that 'Augustinian' Christian philosophers would not likewise be prepared to discover and correct mistakes in their own understanding of faith. See on this point, e.g., Alvin Plantinga, 'On Method in Christian Philosophy. Reply to Keller', in Faith and Philosophy, 5 (1988), 159-164 (especially 161f.). 


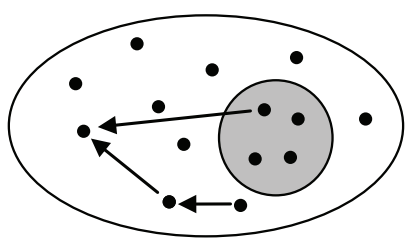

Augustinian pattern of argument

On the Augustinian conception, the logical support-relations in philosophical arguments may also depart from revealed propositions, and such arguments may support propositions not directly pertaining to doctrinal matters.

\section{A CONTEMPORARY EXAMPLE: ALVIN PLANTINGA AND 'REFORMED EPISTEMOLOGY'}

Perhaps the most prominent and influential contemporary example of an explicitly 'Augustinian' conception of Christian philosophy is Alvin Plantinga and his project of 'Reformed Epistemology'. Presuming that a big part of this journal's readership is familiar with Plantinga's ideas in the philosophy of religion, ${ }^{17}$ I constrain myself to some facets of his thought which are directly pertinent to my present topic. As Plantinga repeatedly made clear from the early 1980 s onwards, ${ }^{18}$ he deliberately understands and develops his project as a form of Augustinian Christian Philosophy': 'It is also perfectly proper to start from what we [philosophers, W.L.] know as Christians.'19 The overall project behind Plantinga's philosophizing might be characterized as: 'Make a proposal from a Christian perspective, wait for objections, and if they come, try to defeat them (i.e., to find 'defeater defeaters').'

${ }_{17}$ Of Plantinga's numerous books on the topic I just mention Reason and Belief in God (Notre Dame: Notre Dame University Press, 1983) (the key text of early Reformed Epistemology), Warranted Christian Belief (New York: Oxford University Press, 2000) (Plantinga's later opus magnum where he elaborates on his position in the current epistemological landscape), and recently Where the Conflict Really Lies. Science, Religion, \& Naturalism (New York: Oxford University Press, 2011) (an application to the adjacent problem of the relation between religious and scientific claims).

18 See, among others, his articles 'Advice to Christian Philosophers', in Faith and Philosophy, 1 (1984), 253-271; 'Augustinian Christian Philosophy', in The Monist, 75 (1992), 291-320.

19 'Advice to Christian Philosophers' (see footnote 18), p. 265. 
'Reformed Epistemology' is an application of this overall strategy to current epistemological problems. What would follow for epistemology if the Christian doctrines were true? Or to put it more concretely: Given that we human beings are really created 'in God's own image' (Genesis $1: 27$ ), that we are equipped with a (perhaps brittle and obfuscated) inprinciple ability to cognize God (the Sensus Divinitatis), and that the Holy Spirit enhances our religious cognition (Plantinga further explicates this in his two 'Aquinas/Calvin models'), ${ }^{20}$ what would follow for our epistemic abilities? - Among others, two consequences might follow.

First, it is plausible that certain people will have (clear or unclear) religious experiences, since God wants to communicate with us. Plantinga describes the content of such experiences as 'manifestation beliefs': in certain religiously significant situations (e.g., experiences of nature, personal encounter, danger and rescue, but especially the reading of the Scripture and community service), beliefs like 'God has created all that', 'God speaks to me now', or 'God should be praised' might emerge in us, and they might well be epistemologically respectable. Hence, projection theories à la Freud, Marx, etc., are wrong: of course, the Christian will admit that some questionable or even insane religious manifestation beliefs occur, but from the Christian viewpoint not every single case of religious manifestation beliefs is just a case of projection, illusion, wishful thinking, group-dynamical fascination, etc. If critics in the Freud / Marx vein would like to justify their 'exceptionless projection' claim, they would have to bear the burden of a proof of the tout court

${ }^{20}$ A question that I can merely mention here concerns the theological adequacy of these premises: Old Testament scholars are usually reluctant to ascribe to the 'tzelem elohim / image of God' of Genesis 1:27 any epistemological implications. The same holds for the 'imago Dei' and related passages in the Old and New Testaments; they rather say something about the human being's dignity and vocation and not about our epistemic abilities. Only in medieval scholastic theological anthropology did some authors begin to explore the possible epistemological consequences of the 'imago Dei' doctrine. Likewise, there is doubt whether a Sensus Divinitatis (the central notion of the Aquinas/Calvin model) was taught by Aquinas or Calvin: Aquinas mentions such a natural cognition of God as a counterargument to his own position (S.Th. I, 2, 1, obi.1) and sees it as an most vague, confused and unreliable ability (S.Th. I, 2, 1, ad 1). As the Reformed German theologian Georg Plasger, one of the leading Calvin scholars of our times, has recently shown, Calvin did not in fact consider a Sensus Divinitatis as a significant theological factor, either in the Institutes (where it appears only peripherally) or elsewhere ('Did Calvin teach a Sensus Divinitatis?', forthcoming). - All that, if correct, would of course not preclude the legitimacy of Plantinga's theological premises. It would just imply that it is not standard theology what is called for here, but essentially his peculiar reading of it. 
falsity of theism and Christianity. The Christian may lean back and wait for this proof.

Secondly, the 'Augustinian' Christian thinker will have a preference for epistemological realism: it is much more plausible that we can really find out truths about our world and not just evolutionary useful, survival-efficient beliefs, as naturalism says. The reason for this is that the omniscient God cognizes truths, and we humans are created in his image, i.e., we share his epistemic abilities to a certain extent. (One facet of this God-similar ability is the convergence of our probability judgments in the light of new evidence, mentioned in section IV.1.)

Plantinga openly admits that the ultimate question whether the Aquinas/Calvin models are true (i.e., whether the Christian doctrines about creation, the Sensus Divinitatis and the Holy Spirit are true and theistic Christian beliefs are thus warranted) must remain open, at least from a philosophical standpoint. The book title Warranted Christian Belief may suggest a bit more here; what Plantinga in fact offers is just a partial answer to this question by providing counter-arguments to six prominent lines of attack to Christian faith. But Plantinga does not overstep the result gained by the early 1980s Reformed Epistemology, which is that it is possible for Christian belief to be epistemologically legitimate. The main new achievement of more recent Reformed Epistemology is the design of a (Christian) model explaining this possible legitimacy.

It might also be interesting to ask how Plantinga's actual philosophical practice squares with his official Augustinianism. And here it might be noted that many of his arguments outside the central tenets of Reformed Epistemology are in fact more 'Thomistic' than 'Augustinian' in nature. For example, most of his defeater-defeaters to anti-religious arguments in Warranted Christian Belief refer to internal inconsistencies, general implausibilities, etc., in these arguments without invoking any theological premises. (I leave it as an issue for further reflection whether finding a defeater-defeater for a proposition $p$ must necessarily avoid circularity by not using $\mathrm{p}$ among the premises. Hence, the very project of defeater-defeater for Christian faith is perhaps necessarily 'Thomistic' in its argumentative structure.) Plantinga's much-discussed evolutionary argument against naturalism ${ }^{21}$ is further evidence in that direction.

${ }^{21}$ J. Beilby (Ed.), Naturalism Defeated? Essays on Plantinga's Evolutionary Argument Against Evil (Ithaca: Cornell University Press, 2002), and Alvin Plantinga, Where the Conflict Really Lies (see footnote 17 above). 
Plantinga tries to show that naturalism is internally self-undermining and this is a Thomistic form of argument. It does not rely on theological premises, it supports the Christian viewpoint only indirectly, by eliminating a rival position. And as a third indication one might collect the many passages across Plantinga's works where (traditional as well as new) theistic arguments receive a very positive value, even if they are not seen as necessary for the rationality of faith. ${ }^{22}$

\section{FINAL REFLECTION: WHY 'THOMISTIC' CHRISTIAN PHILOSOPHY SEEMS PREFERABLE}

Observations like those just mentioned may invite consideration of whether a 'Thomistic' standpoint in philosophy has in sum perhaps more to recommend it. In the following final reflections, I want to substantiate this presumption. I do this using Plantinga's 'Augustinian' position as a contrast, but I should begin with two disclaimers: first, I do not intend a critical analysis of Plantinga's position (which would be quite an odd task to attempt in a few lines), and second, I am aware that the issues in question are connected with very fundamental claims concerning the task of philosophy, etc., for which knock-down arguments in any direction are not to be expected. Hence, my remarks do not claim to be more than reasoned declarations of a philosophical preference.

First and very generally, by its very idea philosophy does not address only a certain community, be it a cultural, linguistic, religious, or another community (see section I). Giving, taking, and critically analyzing philosophical reasons are activities that surpass the borders of intellectual communities: they involve stepping back from one's own habitual way of thinking, taking an impartial standpoint (as far as possible), and considering reasons from that perspective. Of course, philosophers (like all people) are entitled to have an opinion on worldview-related issues, and they will be more prepared to give reasons for them than other people will be. But it is only of limited advantage if these reasons are based on sources which many of their dialogue partners will not accept from the outset.

One could, of course, recall a useful distinction between personal and interpersonal arguments: ${ }^{23}$ interpersonal arguments rest only on premises

22 See, e.g., 'Augustinian Christian Philosophy' (see footnote 18), p. 294.

${ }^{23}$ See Otto Muck, Rationalität und Weltanschauung (Innsbruck - Wien: Tyrolia, 1999), pp. $113 f$. 
which are expected to be mutually acceptable, whereas personal arguments may also draw from some premises which are not. Personal arguments are by no means idle: they make an interlocutor's thinking and acting understandable and by that help avoid unnecessary misunderstandings and other irritations. In that sense, one might describe 'Augustinian' Christian philosophy as making more liberal use of personal (Christian) argumentation than the 'Thomistic' Christian philosopher. Nevertheless, the fertility of personal arguments in philosophical dialogue is obviously limited. It is hence not by chance when Plantinga himself switches to rather 'Thomistic' and more interpersonal forms of argument in his attempts to defeat forms of anti-religious thought.

Secondly, 'Augustinian' Christian philosophy must at certain points make use of theological concepts and hence inherits the hermeneutical problems of theology. The problem here is not only that not every philosopher is knowledgeable and competent in theology; a deeper problem lurks in the different ways of understanding theological concepts within theology itself. Philosophers invoking theological concepts may produce positions which are as interesting and acceptable as their chosen background theologies are. And there is a certain danger of producing views which are acceptable neither for most philosophers nor even for a bigger percentage of the theological audience. Plantinga's Reformed Epistemology provides an example: It may at first glance seem convincing to reconstruct manifestation beliefs formed from religious experience as being similar to beliefs formed on the basis of perception and memory; nevertheless this presupposes a certain understanding of God, creation, the ways of communication between man and God, such as the Sensus Divinitatis, etc. The aforementioned theological discussions (see footnote 20) about the Sensus Divinitatis and Plantinga's particular understanding of it may serve as a warning against importing parochial theological views into the philosophical discourse.

Third, one might reverse my first argument and look at it from a theological point of view. From that perspective it seems questionable to what extent an 'Augustinian' Christian philosophy would really be helpful for Christians who have doubts about their faith. Would primarily internal 'defeater-defeaters' against attacks from outside be sufficient, in the face of more than 300 years of religious criticism and against the backdrop of a religiously pluralist society? Or should there be more attention to external justifications, as 'Thomistic' Christian philosophy emphasizes? Again, it is interesting to observe that Plantinga's 
defeater-defeaters are in many cases rather 'Thomistic' in their overall pattern.

I conclude that there is no in-principle obstacle to the use of 'Christian Philosophy' as a label for philosophical positions. In light of the above considerations, it might even be a matter of transparency and sincerity to lay bare any possible influences from the worldview within which one operates. However, all in all the 'Thomistic' self-understanding of 'philosophizing Christians' (even when they are conscious of their possible worldview-driven preferences) seems to have more to recommend it, whereas an 'Augustinian Christian philosophy' seems to be inherently subject to the dangers of parochialism and of blending philosophy and theology in a questionable way. ${ }^{24}$

24 This paper was originally presented in Berlin, at a workshop 'Reasoning from different religious perspectives' (14-15 March 2013) for the Analytic Theology Project, which was generously funded by the John Templeton Foundation. I am indebted to the participants of this workshop for their feedback and especially to Katherine Dormandy (née Munn) for her linguistic assistance and numerous helpful comments on an earlier version of this paper. 